\title{
Appendicular Mucosal Tube Implant with Dartos Wrap Operation for Hypospadias
}

\author{
Sagar Jawale \\ Jawale Institute of Pediatric Surgery, Jalgaon, Maharashtra, India \\ Email: drsagarjawale@gmail.com
}

How to cite this paper: Jawale, S. (2020) Appendicular Mucosal Tube Implant with Dartos Wrap Operation for Hypospadias. Open Journal of Urology, 10, 134-144. https://doi.org/10.4236/oju.2020.105015

Received: March 1, 2020

Accepted: April 23, 2020

Published: April 26, 2020

Copyright (C) 2020 by author(s) and Scientific Research Publishing Inc. This work is licensed under the Creative Commons Attribution International License (CC BY 4.0).

http://creativecommons.org/licenses/by/4.0/

\begin{abstract}
Aims and Objective: To develop a better operation for hypospadias patients with poor and bad quality urethral plate and damaged urethral plate as in hypospadias cripples. Materials and Methods: I operated 21 cases of hypospadias with Appendicular mucosal tube implant with Dartos wrap operation from 17/04/2017 to 03/03/2019, in Jawale Institute of pediatric Surgery, and that group was labeled as group A. 27 cases of hypospadias were operated in same time span with conventional techniques such as extended Snodgrass operation and Byar's two-stage operation (group B), kept as control. 7 patients $(33.33 \%)$ were cases of hypospadias cripples with multiple surgeries done in the past. 4 patients (9.52\%) patients had congenital short urethra. Remaining 10 patients (50\%) were fresh cases with no operation done in past but with bad and fibrotic urethral plate. The longest follow up was 3 years and the shortest of 1 year. Technique of Operation: Appendicectomy performed by open technique and the serosa of Appendix cut longitudinally and stripped off the mucosal tube. The proximal hypospadias opening sutured with the appendicular mucosal tube with 6 sutures of 5-0 Vicryl. Dartos fascia is raised from the scrotum wrapped over the tube and $8-10$ interrupted stitches taken with 5-0 Vicryl. Glanuloplasty performed over it. Suprapubic diversion did and kept for 3 weeks postoperatively. Results: In group A, 3 patients developed fistula and only $1(4.76 \%)$ required repair at the end of 6 weeks. $2(9.52 \%)$ patients developed grade 3 infection and settled with conservative treatment. UFR was normal at the end of 12 weeks $(12.85 \mathrm{Ml} / \mathrm{sec}$. In group B, 11 patients developed fistula and 9 (33.33\%) required repaired. 9 (33.33\%) patients developed strictures and all of them required multiple urethral dilatation under GA. 7 (25.92\%) patients developed meatal stenosis.UFR was badly reduced with average of $5.78 \mathrm{ML} / \mathrm{Sec}$. Conclusion: The operation proves to be a much better option compared to the conventional for group A patients. We need a series with longer follow up and larger number of patients.
\end{abstract}




\section{Keywords}

Hypospadias, Hypospadias Cripples, Appendicular Mucosal Tube Implant, Appendicular Mucosal Tube Implant with Dartos Wrap

\section{Introduction}

The incidence of hypospadias [1] is generally 1 in 200 live births. There are a variety of operations described for hypospadias. Results of hypospadias surgery largely depend on quality of urethral plate. Generally, the variety of operations available for hypospadias has bad results when the quality of urethral plate is poor. There are a good number of cases done by less qualified doctors with multiples surgeries done which destroy the urethral plate, known as hypospadias cripples. Such patients also have poor results with the conventional operations. The conventional operations described in medical literature for above type of patients are Byar's two staged urethroplasty, extended Snodgrass operation, Buccal mucosa urethroplasty, bladder mucosa urethroplasty and Duckett's transverse island operation. All these operations are technically demanding and have a very high complication rate. I am describing an operation here which is technically less demanding and has much lower complication rates than the above options.

Aims and objectives: To develop a better operation for hypospadias with poor and bad quality urethral plate and damaged urethral plate as in hypospadias cripples

\section{Materials and Methods}

I operated 21 cases of hypospadias with Appendicular mucosal tube implant with Dartos wrap operation from 17/04/2017 to 03/03/2019, in Jawale Institute of pediatric Surgery, and that group was labeled as group A (Table 1). Age range for group A was 1 year to 13 years. 7 patients (33.33\%) were cases of hypospadias cripples (Table 1) with multiple surgeries done in the past. 4 patients (9.52\%) patients had congenital short urethra. Remaining 10 patients (50\%) were fresh cases with no operation done in past but with bad and fibrotic urethral plate (Table 1). The appendicular mucosal tube implant with Dartos wrap operation involves using appendicular mucosal tube and implanting it in place of urethra and is wrapped by Dartos fascia. In the same time span, and 27 cases were operated with conventional techniques such as extended Snodgrass operation and Byar's two-stage operation and this group was labelled as group B which is kept as control. The extended Snodgrass operation involves taking a midline cut in the entire urethral plate and tabularizing it over a stent. In Byar's stage one operation, the urethral plate is excised and both skin flaps sutured in the midline to replace the urethral plate. In Byar's stage two operation, the urethra is made by tabularizing the skin. Age range for group B was 11 months to 12 years. The patients were distributed to both groups in a random manner. The variables to 
Table 1. Group A patients operated by appendicular mucosal tube implant with Dartos wrap operation.

\begin{tabular}{|c|c|c|c|c|c|c|c|c|c|}
\hline $\begin{array}{l}\text { Sr. } \\
\text { No. }\end{array}$ & Clinical Features & $\begin{array}{l}\text { Age } \\
\text { (Yr) }\end{array}$ & $\begin{array}{l}\text { Degree of } \\
\text { Chordee }\end{array}$ & Urethral plate & $\begin{array}{l}\text { Position of } \\
\text { meatus }\end{array}$ & $\begin{array}{l}\text { Post-op } \\
\text { cosmetic result }\end{array}$ & $\begin{array}{l}\text { Follow up } \\
\text { (Year) }\end{array}$ & $\begin{array}{l}\text { UFR at } 12 \\
\text { wksMl/Min }\end{array}$ & Complications \\
\hline 1 & $\begin{array}{c}\text { Hypospadias cripples with } \\
3 \text { operation in past }\end{array}$ & 7 & 45 & $\begin{array}{l}\text { Badly damaged and } \\
\text { fibrotic }\end{array}$ & Proximal & Average & 5 & 15 & Grade 3 infection \\
\hline 2 & $\begin{array}{l}\text { No operations in past, } \\
\text { small penile size }\end{array}$ & 7 & 90 & Narrow and fibrotic & Proximal & Good & 5 & 12 & nil \\
\hline 3 & $\begin{array}{c}\text { Hypospadias cripples with } \\
7 \text { operation in past }\end{array}$ & 12 & 30 & $\begin{array}{l}\text { Damaged urethral } \\
\text { plate with fibrosis }\end{array}$ & Perineal & Poor & 4 & 10 & $\begin{array}{l}\text { Fistula required } \\
\text { surgical closure }\end{array}$ \\
\hline 4 & $\begin{array}{l}\text { No operations in past, } \\
\text { small penile size }\end{array}$ & 3 & 60 & Narrow and fibrotic & Proximal & Good & 4 & 15 & nil \\
\hline 5 & $\begin{array}{c}\text { No operations in past, } \\
\text { small penile size, congenital } \\
\text { short urethra }\end{array}$ & 7 & 90 & Small and narrow & Subcoronal & Good & 3.5 & 12 & nil \\
\hline 6 & $\begin{array}{l}\text { No operations in past, } \\
\text { small penile size }\end{array}$ & 9 & 60 & Narrow fibrotic & Proximal & Excellent & 3 & 15 & nil \\
\hline 7 & $\begin{array}{c}\text { Hypospadias cripples with } \\
2 \text { operation in past }\end{array}$ & 5 & 30 & $\begin{array}{l}\text { Badly damaged and } \\
\text { fibrotic }\end{array}$ & Proximal & Good & 3 & 16 & Grade 3 infection \\
\hline 8 & $\begin{array}{l}\text { No operations in past, } \\
\text { small penile size }\end{array}$ & 7 & 90 & Narrow and fibrotic & Midpenile & Average & 2.5 & 12 & nil \\
\hline 9 & $\begin{array}{c}\text { No operations in past, } \\
\text { small penile size, congenital } \\
\text { short urethra }\end{array}$ & 2 & 90 & Small and narrow & Mid penile & Good & 2.5 & 14 & nil \\
\hline 10 & $\begin{array}{c}\text { Hypospadias cripples with } \\
2 \text { operation in past }\end{array}$ & 7 & 30 & $\begin{array}{l}\text { Damaged urethral } \\
\text { plate with fibrosis }\end{array}$ & Proximal & Excellent & 2.5 & 15 & $\begin{array}{c}\text { Post op hematoma, } \\
\text { drained } \\
\text { successfully }\end{array}$ \\
\hline 11 & $\begin{array}{l}\text { No operations in past, } \\
\text { small penile size }\end{array}$ & 2 & 90 & Narrow and fibrotic & Mid Penile & Good & 2 & 12 & nil \\
\hline 12 & $\begin{array}{c}\text { Hypospadias cripples with } \\
3 \text { operation in past }\end{array}$ & 7 & 30 & Fibrotic and scarred & Proximal & Average & 2 & 15 & nil \\
\hline 13 & $\begin{array}{l}\text { No operations in past, } \\
\text { small penile size }\end{array}$ & 2 & 60 & Narrow and fibrotic & Mid penile & Excellent & 2 & 12 & nil \\
\hline 14 & $\begin{array}{l}\text { No operations in past, } \\
\text { small penile size }\end{array}$ & 5 & 90 & Narrow and fibrotic & Perineal & Good & 1.5 & 15 & nil \\
\hline 15 & $\begin{array}{c}\text { No operations in past, } \\
\text { small penile size, congenital } \\
\text { short urethra }\end{array}$ & 2 & 60 & Small and narrow & Proximal & Average & 1.5 & 15 & $\begin{array}{l}\text { Fistula healed on } \\
\text { conservative } \\
\text { treatment }\end{array}$ \\
\hline 16 & $\begin{array}{c}\text { Hypospadias cripples with } \\
2 \text { operation in past }\end{array}$ & 5 & 30 & $\begin{array}{l}\text { Damaged and } \\
\text { scarred }\end{array}$ & Mid penile & Good & 1.5 & 12 & nil \\
\hline 17 & $\begin{array}{l}\text { No operations in past, } \\
\text { small penile size }\end{array}$ & 13 & 90 & Narrow, small penis & Perineal & Good & 1.5 & 10 & $\begin{array}{c}\text { Post op hematoma, } \\
\text { drained } \\
\text { successfully }\end{array}$ \\
\hline 18 & $\begin{array}{l}\text { No operations in past, } \\
\text { small penile size }\end{array}$ & 11 & 60 & Narrow and fibrotic & Mid penile & Excellent & 1 & 12 & nil \\
\hline 19 & $\begin{array}{c}\text { Hypospadias cripples with } \\
5 \text { operation in past }\end{array}$ & 12 & 30 & $\begin{array}{l}\text { Badly damaged with } \\
\text { scars }\end{array}$ & Proximal & Poor & 1 & 16 & $\begin{array}{l}\text { Fistula healed on } \\
\text { conservative } \\
\text { treatment }\end{array}$ \\
\hline
\end{tabular}




\section{Continued}

\begin{tabular}{|c|c|c|c|c|c|c|c|c|c|}
\hline 20 & $\begin{array}{l}\text { No operations in past, } \\
\text { small penile size, congenital } \\
\text { short urethra }\end{array}$ & 9 & 60 & Small and narrow & Perineal & Excellent & 1 & 14 & nil \\
\hline 21 & $\begin{array}{l}\text { No operations in past, } \\
\text { small penile size }\end{array}$ & 8 & 90 & Small and fibrotic & Proximal & Good & 1 & 16 & nil \\
\hline
\end{tabular}

be compared in two groups are fistula rates, redo operation rate, other complications, UFR at the end of 12 weeks and the cosmetic results. The variables in both groups were compared by calculating the percentage of each variable. Patients were followed up at monthly interval for first 3 months and 3 months till 3 years. The longest follow up was 3 years and the shortest of 1 year.

Technique of operation: Two days before the surgery, patient is subjected to mechanical bowel cleansing and antibiotics are given to reduce bacterial load in the colon. Under general anesthesia open appendicectomy is performed by the conventional open technique (Figure 1). Incision is taken at McBurney's point and deepened through muscles to open peritoneal cavity. The appendix is identified and held by atraumatic.

Babcock's forceps to avoid damage. Appendicular artery is divided between ligatures without damaging the appendix. The appendix is ligated at the base with 3-0 vicryl and distal appendix excised. The appendicular stump is cauterized with cautery and buried by 3-0 vicryl. The muscles closed by interrupted 3-0 vicryl. Skin closed by 3-0 vicryl subcuticular sutures. The appendicectomy can also be performed by laparoscopy, but my choice was open surgery.

A small cut is made in the terminal part of appendix. No.10 infant feeding tube coated with KY jelly passed through the appendix through and through. The serosa of appendix cut longitudinally and stripped off the mucosal tube (Figure 2) without creating a breach in it. Blunt and sharp dissection are needed to accomplish this step. Now the serosa is completely excised and only mucosal tube is left. The mucosal tube scrapped with a blunt scalpel to strip of any remaining part of submucosa and muscularis to keep only the mucosal tube (Figure 3). The tube is kept in Metronidazole solution (500 mg in $100 \mathrm{ml}$ ) for 10 minutes to disinfect it.

A glans stitch is taken by $4-0$ vicryl on round body needle. The penile skin is degloved till the base of the penis. The urethral plate or its remnants are fully excised. Any chordee tissue around and below urethral plate is completely excised. Chordee test is performed by applying tourniquet at the base of penis and by injecting saline in corporal bodies through glans penis. Thus, it is confirmed that there is no residual chordee. The proximal hypospadias opening mobilized for 1 $\mathrm{cm}$ and any fibrous tissue around it excised. The $5 \mathrm{~mm}$ distal part of the opening is excised to have healthy tissue for anastomosis.

A midline incision is taken on median raphe of scrotum. Dartos fascia which is medial and inferior to the testis dissected off from the skin and testis on both sides (Figure 4). Dissection is performed and Dartos fascia separated from perineal 


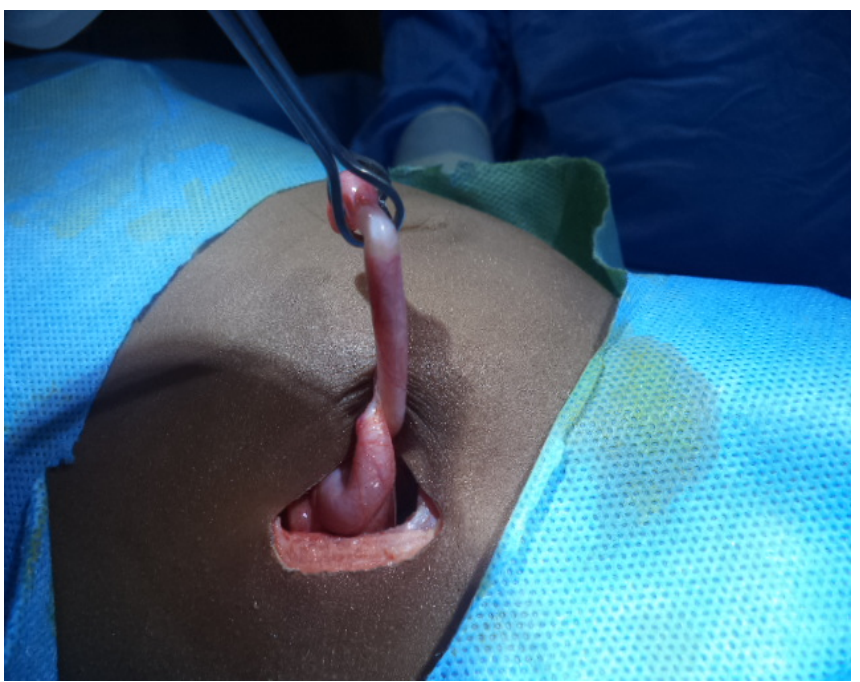

Figure 1. Appendicectomy performed by open technique.

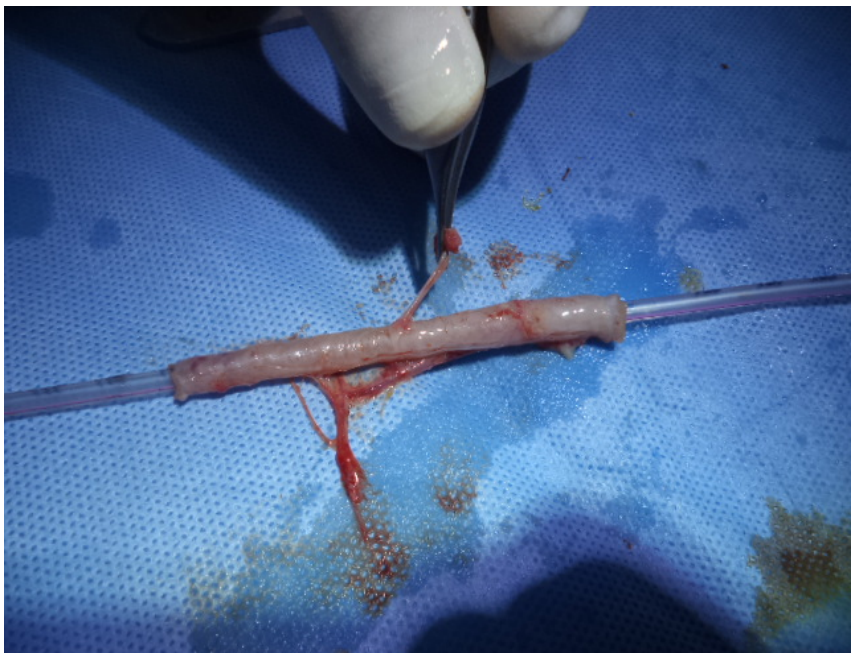

Figure 2. Serosa and muscularis stripped off the appendicular mucosal tube.

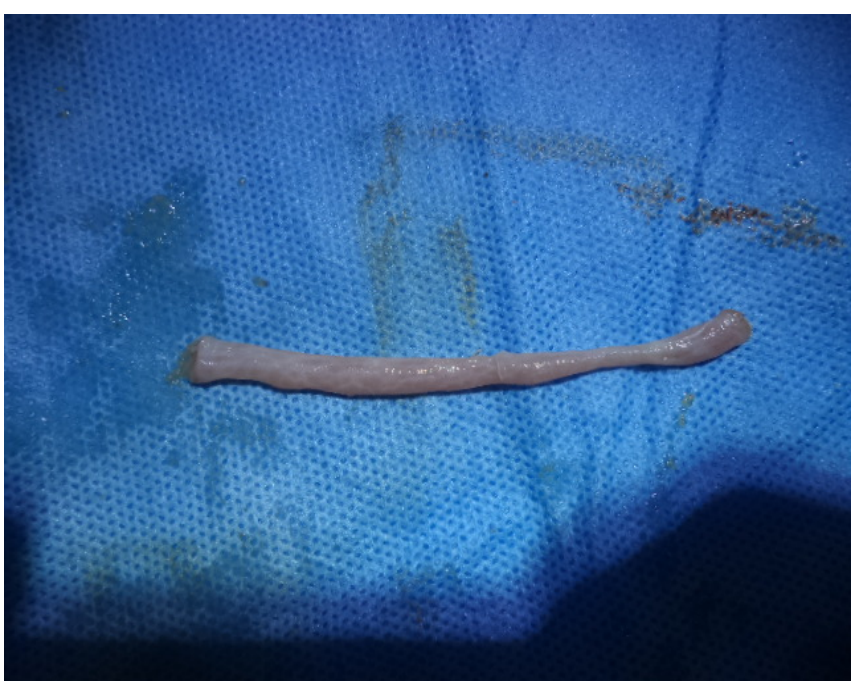

Figure 3. Appendicular mucosal tube ready for implantation. 


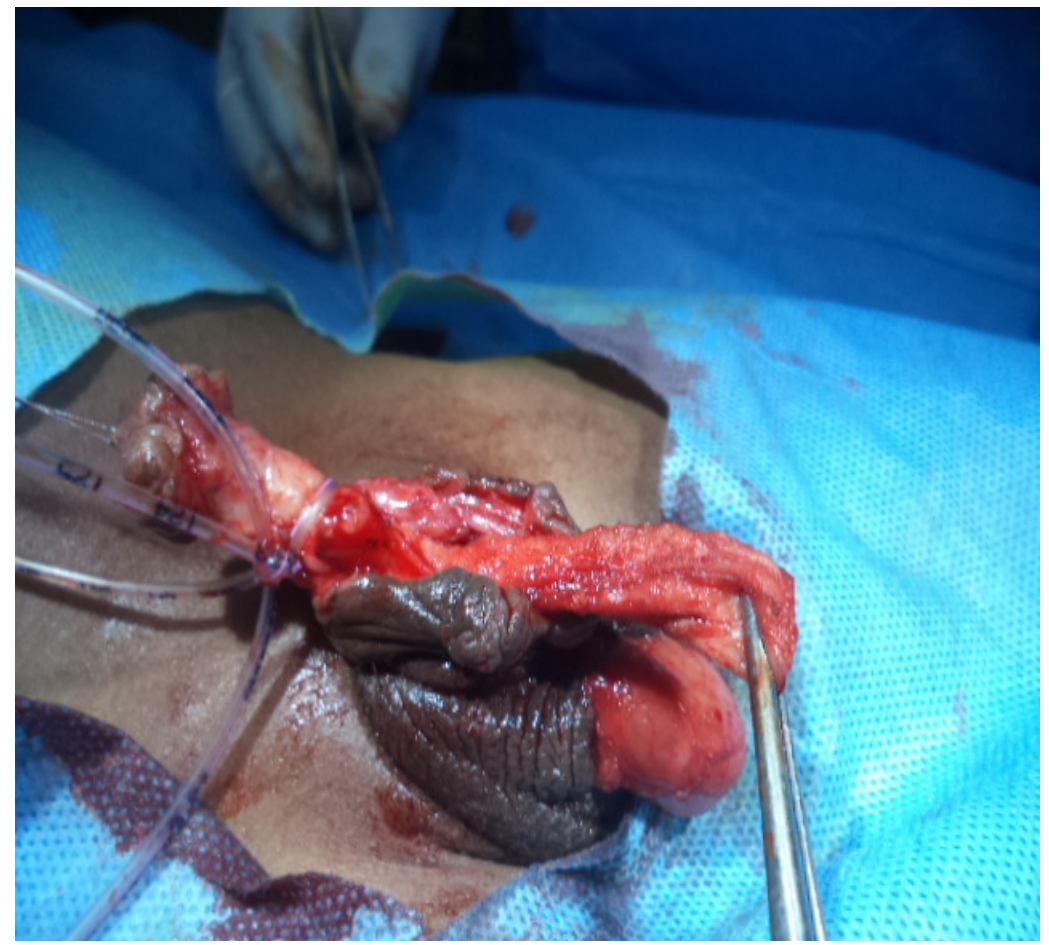

Figure 4. Dartos fascia raised from scrotum.

urethra. Dartos fascia lengthened till it comfortably reaches the tip of glans penis. Midline incision was taken ventrally on glans penis and glans wings raised on both sides. Dartos fascia now sutured to the tip of glans penis (Figure 5) in the midline by 5-0 Vicryl suture. The dartos fascia now forms a vascular bed (Figure 5) over the underlying Buck's fascia. A hole is made in Dartos fascia at the level of proximal opening of hypospadias that is already created. This opening is taken out through the hole in Dartos fascia.

The appendicular mucosal tube anastomosed with proximal urethral opening by 6 interrupted sutures of 5-0 Vicryl (Figure 6). The Dartos is wrapped over the appendicular mucosal tube and proximal anastomosis (Figure 7) by taking 8 10 interrupted stitches with 5-0 Vicryl. The distal end of the tube is passed through raised glans wings along with the Dartos wrapped around it. The pale mucosal tube immediately starts looking pink.

Glanuloplasty performed over it by 5-0 Vicryl horizontal mattress sutures. Penile skin cut vertically in the midline to raise Byar's skin flaps. Both the flaps moved ventrally forwards and sutures to each other as well as to the glans penis (Figure 8).

Penis is wrapped by Soffratulle and a gauze piece over it. A compression dressing gave over it by wrapping with Elastoplast bandage. A suprapubic diversion was done by putting No. 12 Foley's catheter into the urinary bladder by open technique. It is kept for 3 weeks postoperatively. Intravenous antibiotics are given in calculated dosages postoperatively for one week. The author's choice is Injection Ceftriaxone, Amikacin and Metronidazole. 


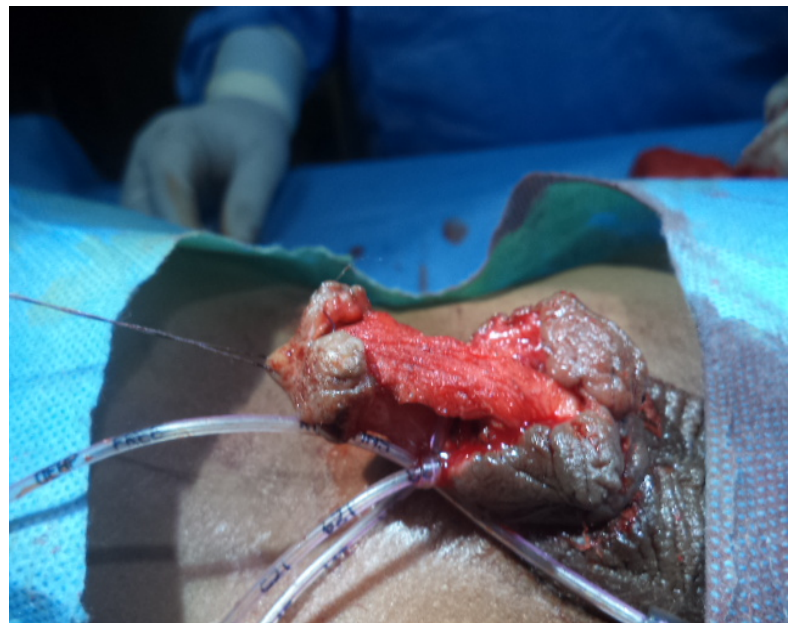

Figure 5. Dartos fascia anchored to the tip of glans penis to create a vascular bed.

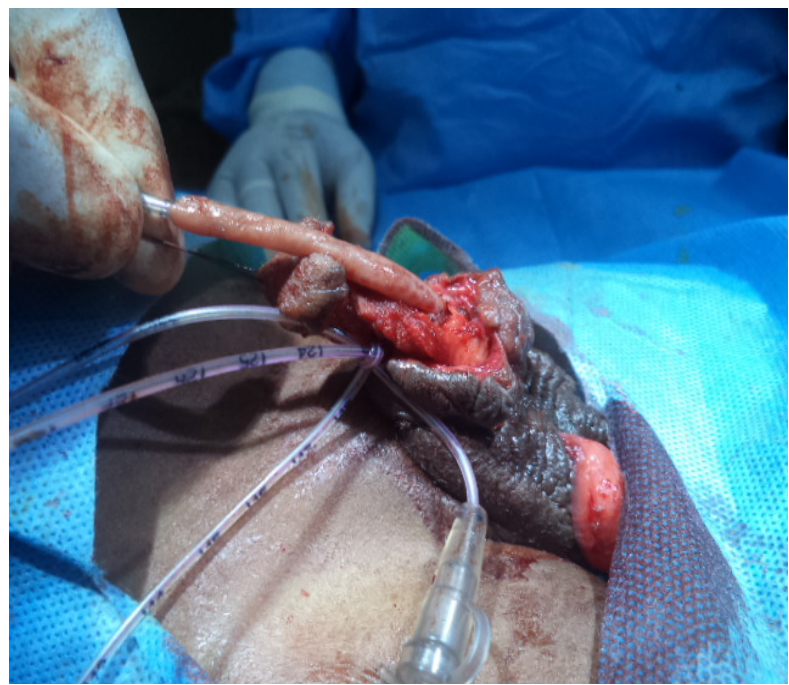

Figure 6. The appendicular mucosal tube anastomosed with proximal urethral opening.

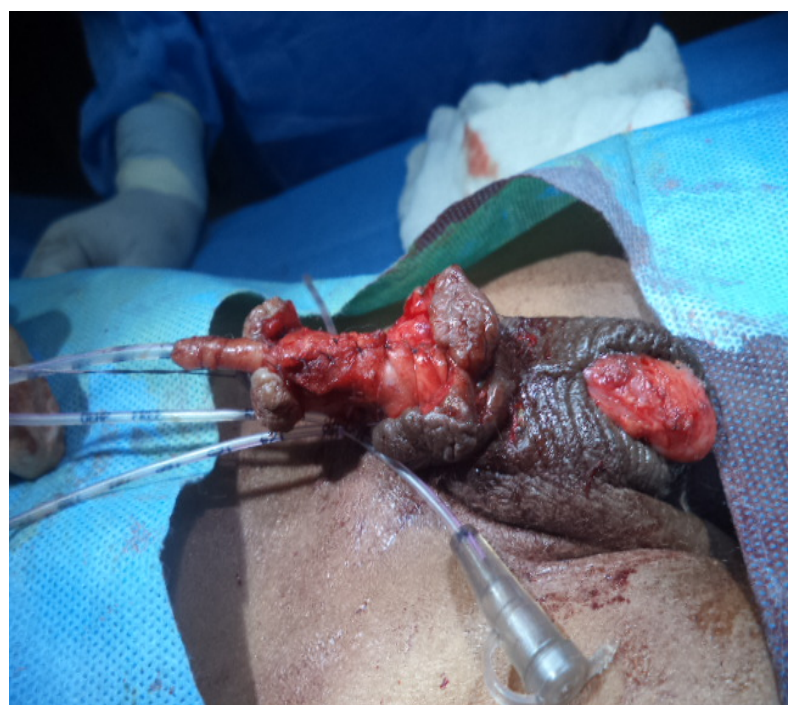

Figure 7. The Dartos is wrapped over the appendicular mucosal tube. 


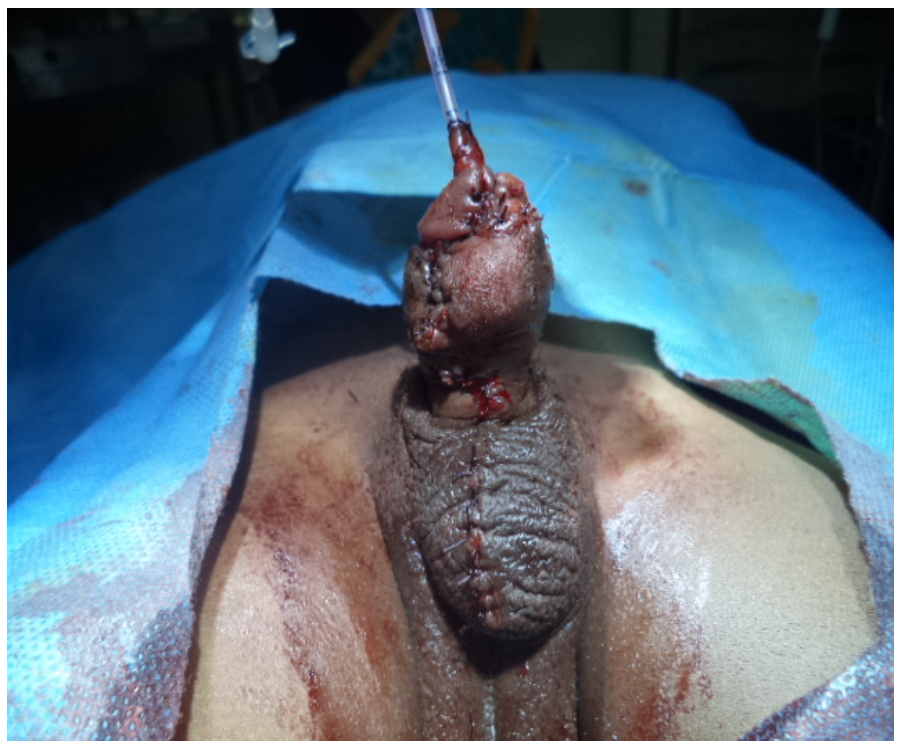

Figure 8. The end result.

\section{Results}

Patients were followed up weekly for 6 weeks and monthly thereafter. Longest follow up was 3 years and shortest of 1 year. In group A, 3 patients developed fistula and only $1(4.76 \%)$ required repair at the end of 6 weeks. $2(9.52 \%)$ patients developed grade 3 infection and settled with conservative treatment. 2 (9.52\%) patients developed hematoma in postoperative period. It was drained successfully by taking a small skin incision and settled with conservative management. No patient developed stricture or stenosis. UFR was normal at the end of 12 weeks with average of $12.85 \mathrm{Ml} / \mathrm{sec}$. The cosmetic result was measured on the scale of excellent, good average and poor. 5 patients (23.8\%) had excellent cosmetic result, 10 patients (47.61\%) had good result, 4 patients $(19.04 \%)$ had average result and only 2 patients (9.52\%) had poor result. In group B, 11 patients developed fistula and $9(33.33 \%)$ required repaired. 9 (33.33\%) patients developed strictures and all of them required multiple urethral dilatation under GA. 7 (25.92\%) patients developed meatal stenosis. UFR was badly reduced with average of $5.78 \mathrm{ML} / \mathrm{Sec}$.

\section{Discussion}

The use of whole appendix with pedicle graft [2] as a replacement of urethra is reported in the medical literature. But it is a complex and time-consuming operation. The appendicular vascular pedicle is short and such operation generally can only replace posterior urethra. Operation with appendix as a free graft [3] with anastomosing its vessels to the local vessels by microvascular technique is also reported. The vascular anastomosis is extremely challenging and prone to complications.

Buccal mucosal urethroplasty [4] and bladder mucosa urethroplasty [5] operations are also described in the literature of hypospadias surgery for hypospadias 
with bad quality of urethral plate. The results of these operations are generally poor and are as follows. In a series of 50 cases of proximal hypospadias, treated with bladder mucosal urethroplasty [5] the long-term complications observed were, urethra-cutaneous fistula in nine patients (18\%), urethral stricture in 15 patients (30\%), meatal stricture in four patients (8\%), and prolapse of meatus in seven patients (14\%).

Early oral complications of buccal mucosal urethroplasty [6] in a series of 21 patients were as follows. Eighteen (85.7\%) patients had mild pain, 13 (61.9\%) had mild intraoral swelling, none of the patients had oral bleeding that needed extra procedure. Twelve (57.1\%) of the 21 patients needed analgesic agents after the operation while $14(66.7 \%)$ of them have remarked that perineal incision was more painful. Twenty (95.3\%) of 21 patients stated that they could go under the same procedure again. None of our patients had speech disorders or intraoral numbness.

The penile complications in a series of buccal mucosa urethroplasty [7] was, wound dehiscence in $2(1.9 \%)$ patients, re-stricture in 11 (10.5\%), fistula in 6 $(5.7 \%)$ patients, meatal stenosis in $3(2.9 \%)$.

The results of my group B patients with 27 cases done by extended Snodgrass operation and Byar's two-stage operation were as follows. 11 patients developed fistula and $9(33.33 \%)$ required repaired. $9(33.33 \%)$ patients developed strictures and all of them required multiple urethral dilatation under GA. 7 (25.92\%) patients developed meatal stenosis.UFR at the end of 12 weeks was badly reduced with average of $5.78 \mathrm{ML} / \mathrm{Sec}$.

The results of my Appendicular mucosal tube implant with Dartos wrap operation (group A) were as follows. 3 patients developed fistula and only 1 (4.76\%) required repair at the end of 6 weeks. $2(9.52 \%)$ patients developed grade 3 infection and settled with conservative treatment. 2 (9.52\%) patients developed hematoma in postoperative period. It was drained successfully by taking a small skin incision and settled with conservative management. No patient developed stricture or stenosis. UFR was normal at the end of 12 weeks with average of $12.85 \mathrm{Ml} / \mathrm{sec}$. The cosmetic result was measured on the scale of excellent, good average and poor. 5 patients (23.8\%) had excellent cosmetic result, 10 patients (47.61\%) had good result, 4 patients (19.04\%) had average result and only 2 patients $(9.52 \%)$ had poor result. It is obvious that the results of this operation are far superior to group B patients and patients with bladder and buccal mucosa urethroplasty.

4 patients in my series (Group A) had congenital short urethra [8]. It is a rare congenital anomaly of urethra where skin forms the ventral wall of the urethra. The treatment of these cases is very challenging as generally entire urethra is to be sacrificed [8]. The treatment is generally done in a staged manner where first stage is done as Byar's stage one urethroplasty. After 6 months, Byar's second stage urethroplasty can be performed. This condition can also be treated as a primary operation by performing Duckett's Onlay flap or a Duckett's transverse island flap urethroplasty operation [8]. Both these operations are technically 
challenging and have high rate of complications. All 4 cases in my series (Group A) were successfully operated as a primary operation by my technique.

According to me, the results of bladder and buccal mucosa urethroplasty are bad because the tubes are placed over Buck's fascia and wrapped by skin over it. The Buck's fascia and penile skin are both avascular tissues. They failed to vascularize the mucosal tube. I suggest that if the Dartos wrap technique is applied for Buccal and bladder mucosa urethroplasty, the results may be substantially superior as the vascular Dartos will vascularize the tubes very well.

Appendicular mucosal tube implant with Dartos wrap operation is superior to the bladder and buccal mucosal urethroplasty for the following reasons. The appendix is a vestigial organ. There are no ethical and moral issues for using it as a replacement of urethra. The bladder and oral mucosa are not vestigial organs. Bladder and buccal urethroplasties have a long suture line and chances of fistula formation are much higher. Contrary to that in my operation, the mucosal integrity of appendicular tube is intact, hence chances of a fistula formation are far less.

The use of appendicular mucosal tube as a replacement of urethra and Dartos wrap over it is reported for the first time in the medical literature. The appendicular mucosal tube being of same patient does not have graft Vs host reaction. The appendicular mucosal tube looks pale like a dead tissue in the bowl before implantation. After implantation and being wrapped by the vascular Dartos fascia, it starts looking pink immediately. The tube receives its early nutrients from the Dartos Fascia by the phenomenon of permeability. The tube acquires blood supply like a split skin graft from the Dartos wrap. The vascular Dartos fascia neovascularizes the tube rapidly. The tube has healthy mucosa, hence does not contract and leads to a stricture. The Dartos which is a tough fibro muscular tissue acts as Corpus Spongiosum which is absent in these patients.

\section{Conclusion}

The operation is an important addition to the armament of a hypospadiologist. The operation proves to be a much better option compared to the conventional for the said category of patients. We need an operative series with longer follow up and larger patient numbers.

\section{Funding}

Self-funded by Dr. Sagar Jawale.

\section{Conflicts of Interest}

The author declares no conflicts of interest regarding the publication of this paper.

\section{References}

[1] Springer, A., van den Heijkant, M. and Baumann, S. (2016) Worldwide Prevalence 
of Hypospadias. Journal of Pediatric Urology, 12, 152.e1-152.e7. https://doi.org/10.1016/j.jpurol.2015.12.002

[2] Aggarwal, S.K., Goel, D., Gupta, C.R., Ghosh, S. and Ojha, H. (2002) The Use of Pedicled Appendix Graft for Substitution of Urethra in Recurrent Urethral Stricture. Journal of Pediatric Surgery, 37, 246-250. https://doi.org/10.1053/jpsu.2002.30265

[3] Hiradfar, M., Shojaeian, R. and Sharifabad, P.S. (2015) Two Staged Modified Substitution Urethroplasty Using Appendix-Free Flap. BMJ Case Reports, 2015 bcr2015210771. https://doi.org/10.1136/bcr-2015-210771

[4] Djordjevic, M.L., Bizic, M., Stojanovic, B., Bencic, M., Kojovic, V. and Korac, G. (2019) Buccal Mucosa Graft for Simultaneous Correction of Severe Chordee and Urethroplasty as a One-Stage Repair of Scrotal Hypospadias (Watch Technique) World Journal of Urology, 37, 613-618. https://doi.org/10.1007/s00345-018-2517-y

[5] Lanciotti, M., Betti, M., Elia, A., Landi, L., Taverna, M., Cini, C. and Masieri, L. (2017) Proximal Hypospadias Repair with Bladder Mucosal Graft: Our 10 Year Experience. Journal of Pediatric Urology, 13, 294.e1-294.e6. https://doi.org/10.1016/j.jpurol.2017.01.011

[6] Akyüz, M., Güneş, M., Koca, O., Sertkaya, Z., Kanberoğlu, H. and Karaman, M.İ. (2014) Evaluation of Intraoral Complications of Buccal Mucosa Graft in Augmentation Urethroplasty. Turkish Journal of Urology, 40, 156-160.

[7] Selim, M., Salem, S., Elsherif, E., Badawy, A., Elshazely, M. and Gawish, M. (2019) Outcome of Staged Buccal Mucosal Graft for Repair of Long Segment Anterior Urethral Stricture. BMC Urology, 19, Article No. 38. https://doi.org/10.1186/s12894-019-0466-4

[8] Gomez, L.A.D., Escariz, P.P. and Gonzalez, F.M. (1981) Congenital Short Urethra. British Journal of Plastic Surgery, 34, 173-177. https://doi.org/10.1016/S0007-1226(81)80089-6 